\title{
PENGARUH KREATIVITAS GURU TERHADAP MOTIVASI BELAJAR SISWA KELAS VII PADA MATA PELAJARAN PAI \& BP DI SMP PLUS DAARUL JANNAH KABUPATEN TANGERANG
}

\author{
Al-Irsyadiyah \\ mrsalirsyadiyah@gmail,com \\ Pendidikan Agama Islam, Fakultas Agama Islam, Universitas Muhammadiyah Tangerang, \\ Jln. Perintis Kemerdekaan I Babakan No.33 Tangerang-Banten
}

\begin{abstract}
The purpose of the study was to determine the effect of teacher creativity on the learning motivation of class VII students at SMP Plus Daarul Jannah, Tangerang Regency. This type of research is field research using a quantitative approach with 30 respondents. The results of this study concluded that the value of the frequency distribution of teacher creativity (variable X) $80 \%$ of 24 students from 30 respondents, the value of the frequency distribution of learning motivation (variable Y) $73.33 \%$ and the magnitude of the influence of teacher creativity on learning motivation obtained linear regression values Sig $<0.05$, namely $0.002<0.05$, then $H o$ is rejected, meaning that the independent variable $(X)$ of teacher creativity significantly affects the variable $(Y)$ namely student learning motivation. Based on the value of $R$ square is also called the coefficient of determination which in this case means that the variable of learning motivation is influenced by the creativity of the teacher by $28.3 \%$. The remaining $71.7 \%$ is influenced by other factors that have not been studied in this study.
\end{abstract}

Keywords: Teacher Creativity, Learning Motivation.

\begin{abstract}
ABSTRAK
Tujuan penelitian untuk mengetahui pengaruh kreativitas guru terhadap motivasi belajar siswa kelas VII di SMP Plus Daarul Jannah Kabupaten Tangerang. Jenis penelitian ini penelitian lapangan dengan menggunakan pendekatan kuantitatif dengan 30 responden. Hasil penelitian ini menyimpulakan; Bahwa di peroleh nilai distribusi frekuensi kreativitas guru (variabel $X$ ) 80\% sebayak 24 siswa dari 30 responden, nilai distribusi frekuensi motivasi belajar (variabel Y) 73,33\% dan besarnya pengaruh kreativitas guru terhadap motivasi belajar diperoleh nilai regresi linier sederhana Sig $<0,05$ yaitu 0,002 < 0,05 maka Ho di tolak, artinya variabel independent $(X)$ kreativitas guru secara signifikan berpengaruh terhadap variabel $(Y)$ yaitu motivasi belajar siswa. Berdasar Nilai $R$ square disebut juga koofisien determinasi yang dalam hal ini berarti variable motivasi belajar di pengaruhi oleh kreativitas guru sebesar 28,3\%. Sisanya $71,7 \%$ di pengaruhi oleh faktor lain yang dalam penelitian ini belum diteliti.
\end{abstract}

Kata Kunci : Kreativitas Guru, Motivasi Belajar.

\section{A. Pendahuluan}

Kreativitas adalah proses mental yang melibatkan pemunculan gagasan dan konsep yang sudah ada. Menurut Jack foster kreativitas merupakan ranah psikologi kompleks dan multidimentional yang mengandung tafsiran yang beragam. Kunci kreativitas adalah ide. Ide menurut 
James web young adalah sebuah kombinasi baru dari unsur- unsur lama, tidak lebih tidak kurang. ${ }^{1}$

Pendidik dalam perspektif pendidikan Islam adalah orang yang bertanggung jawab dengan menupayakan perkembangan seluruh potensi baik potensi efektif, kognitif, maupun psikomotorik sesuai dengan ajaran agama islam. Peserta didik merupakan subjek dan objek. Oleh karena itu proses pendidikan tidak akan terlakssana tanpa peserta didik didalamnya. ${ }^{2}$ Nilai sikap dan keterampilan keagamaan pada pengalaman ajaran islam yang meliputi nilai akhlak dan budi pekerti seperti: jujur, hormat kepada orang tua, amanah, istiqomah, empati dan semangat mencari ilmu ${ }^{3}$.

Guru sebagai pelaku utama dalam penerapan program pendidikan untuk mengembangakan potensi peserta didik agar menjadi manusia yang beriman dan bertaqwa kepada Tuhan yang Maha Esa, berakhlak mulia, sehat, berilmu, cakap, kreatif, mandiri serta menjadi warga negara yang demokratis dan bertanggung jawab. ${ }^{4}$ Belajar merupakan tingkah laku atau serangkaian kegiatan misalnya dengan membaca mengamati, mendengarkan, meniru dan lain sebagainya. ${ }^{5}$ Tujuan belajar adalah ingin mendapatkan pengetahuan, keterampilan dan penanaman

${ }^{1}$ Sri narwati, creative learning kiat menjadi guru kreatif dan favorit (Yogyakarta: Kamilia,2017). h.4-5

${ }^{2}$ Abdul basyit dan sahlani, Ilmu Pendidikan Islam (Banten : Pustaka Getok tular, 2017) h. 41

${ }^{3}$ Muhammad ahsan, sumiyati dan Mustahdi, Pendidikan Agama Islam dan Budi Pekerti (Jakrta : Kemendikbud, 2017) h.223

${ }^{4}$ Hamza B Uno dan Nurdin Muhammad, Belajar dalam pendekatan PAIKEM (Jakarta : Bumi aksara, 2014). h.152

${ }^{5}$ Sardiman AM, Interaksi dan Motivasi Belajar Mengajar (Depok: PT. Raja Grafindo Persada, 2018)h.20-21 sikap mental atau nilai-nilai. ${ }^{6}$ Guru dalam melaksanakan tugasnya sebagai pendidik minimal ada dua fungsi, yakni fungsi moral dan fungsi kedinasan. ${ }^{7}$ Kreativitas mutlak sangat diperlukan dari para pendidik dari orang tua agar membuat siswa aktif dan termotivasi dan terus belajar. ${ }^{8}$ Motivasi adalah perubahan emosi dalam diri seseorang yang ditandai dengan timbulnya dan reaksi untuk mencapai tujuan. ${ }^{9}$

\section{B. Kajian Teori}

1. Kreativitas Guru

a. Pengertian Kreativitas

Kreativitas adalah kemampuan umum untuk menciptakan sesuatu yang baru sebagai kemampuan untuk memberikan gagasan baru yang dapat diterapkan dalam pmecahan masalah, atau sebagai kemampuan untuk melihat hubungan-hubungan baru atau unsurunsur yang sudah ada. ${ }^{10}$

b. Faktor- faktor yang mempengaruhi kreativitas

1). Faktor pendorong: (a). kepekaan dalam melihat lingkungan (b) kebebasan dalam bertindak (c) komitmen untuk maju dan berhasil (d) optimis dan berani ambil resiko (e) ketekunan untuk berlatih (f) hadapi masalah sebagai tantangan (g) lingkungan kondusif, tidak kaku dan otoriter

2). Faktor-faktor penghambat: (a) malas berpikir, bertindak dan melakukan sesuatu (b) influsif (c) menganggap remeh karya orang lain (d) mudah putus asa (e) cepat puas (f)

${ }^{6}$ Ibid, .28

${ }^{7}$ Ibid,. 140

${ }^{8}$ Juwariyah, Dasar-dasar Pendidikan Anak dalam Al-qur'an (Yogyakarta: Teras, 2010)h. 91-92

${ }^{9}$ Sahlan asnawi, Teori Motivasi (Jakarta: PT. Studia Pres, 2002). h.13

${ }^{10}$ Utami munandar, Pengenbangan Kreativitas Anak Berbakat (Jakarta : Rineka cipta, 2009)h.25 
tidak berani menanggung resiko (g) tidak percaya dulu ${ }^{11}$

c. Ciri - ciri Kreativitas

Kreativitas ditandai dengan adanya kegiatan seseorang untuk menciptakan sesuatu yang sebelumnya tidak ada dan tidak dilakukan oleh seseorang untuk menciptakan sesuatu yang baru. ${ }^{12}$

2. Motivasi Belajar

a. Pengertian Motivasi; Motivasi belajar adalah perubahan mental pada diri seseorang sehingga menghasilkan sesuatu yang bermnfaat bagi diri prilaku dan orang lain. ${ }^{13}$

b. Fungsi Motivasi: (a) mendorong manusia untuk berbuat, (b) menetukan arah perbuatan (c) menyeleksi perbuatan ${ }^{14}$

c. Macam-macam motivasi: (1) motivasi dilihat dari dasar pembentukannya : motif-motif bawaan, motif yang dipelajari (2) motivasi instrinsik dan ekstrinsik, ialah yang berasal dari dalam diri dan lingkungan. ${ }^{15}$

3. Pengaruh kreativitas guru terhadap motivasi belajar siswa

Guru dan orang tua yang kreativ sangat berpengaruh dalam proses pendidikan anak. Karna itu kreativitas mutlak diperlukan dari para pendidik dan orang tua agar dengan cara-cara yang menyenangkan dapat membuat siswa aktif dan termotivasi untuk terus belajar sehingga pemahaman yang benar

${ }^{11}$ Hamza Buno dan Nurdin Muhammad, Belajar Dalam Pendekatan PAIKEM (Jakarta: Bumi aksara, 2014)h.155

${ }^{12}$ Mulyasa, menjadi guru professional menciptakan pembelajaran kreatif dan menyenangkan (Bandung : Remaja Rosda Karya , 2009) h. $51-52$

${ }^{13}$ Ngalim Purwanto, Psikologi pendidikan (Jakarta : PT. Rosda karya, 2014) h. 73

${ }^{14}$ Sardiman AM, interaksi dan motivasi belajar mengajar (Depok: PT.Raja Grafindo Persada, 2018) h.85

${ }^{15}$ Ibid,. 90-91 terhadap anak akan membuat pola dan aktifitas pendidikan menjadi optimal. ${ }^{16}$

\section{Metode Penelitian}

1. Metode Penelitian; Dalam penelitian ini menggunakan pendekatan kuantitatif, yang bersifat regresional yang mempengaruhi dua variabel. Metode yang digunakan dalam penelitian ini menggunakan metode survey. Dalam survey tidak ada perubahan yang dilakukan dalam variabel tertentu, meneliti apa adanya. ${ }^{17}$

2. Populasi dan Teknik Pengambilan Sampel; Populasi adalah wilayah generalisasi yang terdiri atas: objek/subjek yang mempunyai kualitas dan karakteristik tertentu yang ditetapkan oleh peneliti untuk dipelajari dan kemudian ditarik kesimpulannya. Sedangkan Teknik Pengambilan Sampel adalah bagian dari jumlah dan karakteristik yang dimiliki oleh populasi tersebut.

3. Instrument Penelitian; Instrument sebagai alat pengumpulan data yang harus betulbetul dirancang dan dibuat sedemikian rupa sehingga menghasilkan data yang empiris sebagaimana adanya. Dengan memberikan penjabaran tentanng definisi konseptual dan operasional, kisi-kisi, validitas, dan reliabilitas.

4. Teknik Pengumpulan Data; Teknik Pengumpulan data yang di mulai dari Teknik Observasi, yakni pengamatan dan pencatatan yang dilakukan terhadap objek yang ada di SMP Plus Daarul Jannah Kabupaten Tangerang. Interview, yakni alat pengumpulan informasi dengan cara mengajukan sejumlah pertanyaan secara lisan untuk dijawab secara lisan pula. Kuesioner, yakni alat pengumpulan informasi dengan cara menyampaikan sejumlah pertanyaan tertulis untuk

${ }^{16}$ Juwariyah, dasar-dasar pendidikan anak dalam alquran (Yogyakarta : Teras, 2010)h.91-92

${ }^{17}$ Sugiono, metode penelitian kuantitatif, kualitatif dan R\&D (Bandung : CV. Alfabeta, 2017) h. 61 
dijawab secara tertulis pula oleh responden.

5. Teknik Anlisis Data; Setelah data dikumpulkan akan dianalisis deskriptif kuantitatif, kemudian dilakukan analisis dengan menggunakan uji regresi linier sederhana untuk menganalisis pengujian hipotesis. Sebelum dilakukan pengujian hipotesis dan analisis, dilakukan uji prasyarat terlebih dahulu terhadap data kreativitas guru terhadap motivasi belajar.

6. Hipotesis Statistik; Ha : Adanya pengaruh antara kreativitas guru terhadap motivasi belajar siswa VII di SMP Plus Daarul Jannah Kabupaten Tangerang.

Ha : Tidak Ada pengaruh antara kreativitas guru terhadap motivasi belajar siswa VII di SMP Plus Daarul Jannah Kabupaten Tangerang.

\section{Hasil Penelitian Dan Pembahasan}

1. Deskripsi Data

Sebagaimana telah dijelaskan bahwa penelitian ini bertujuan untuk mengetahui apakah terdapat pengaruh antara kreativitas guru terhadap motivasi belajar siswa siswa kelas VII di SMP Plus Daarul Jannah Kabupaten Tangerang. Penelitian ini terdiri dari dua variabel, yang satu variabel bebas dan yang satu variabel terikat. Berdasarkan hasil hitungan distribusi frekuensi pada variabel bebas dapat dikatakan bahwa variabel bebas $(\mathrm{x}) /$ kreativitas guru dalam kategori sedang dengan persentase $80 \%$. Sedangkan variabel terikat $(\mathrm{y}) /$ motivaasi belajar siswa dalam kategori sedang dengan persentase 73,33\%.

2. Pengujian Persyaratan Analisis

a. Uji Normalitas variabel $X$ dan variabel $Y$ Uji normalitas menggnakan shapiro wilk. Adapun dasar pengambilan keputusan Jika sig>0,05 maka data berdistribusi normal Jika sig <0,05 maka data berdistribusi tidak normal

Dari perhitungan data dapat kita simpulkan bahwa nilai sig variabel $X$ $(0,093)$ yang berarti lebih besar dari $(0,05)$ maka variabel $X$ berdistribusi normal. Jika sig variabel $Y(0,288)$ yang berarti lebih besar dari $(0,05)$ maka variabel $Y$ berdistribusi normal.

b. Uji Homogenitas

Uji homogenitas dilakukan dengan uji levene, dengan dasar keputusan: Jika sig < 0,05, maka dinyatakan tidak homogenitas Jika sig > 0,05, maka dinyatakan homogenitas Berdasarkan output hasil SPSS bahwa nilai signifikan variabel kreativitas guru terhadap motivasi belajar siswa adalah 0,239>0,05, artinya kretivitas guru terhadap motivasi belajar siswa kelas VII mempunya varian yang sama atau homogenitas.

3. Pengujian Hipotesis

Penganbilan keputusan dimana, variabel (x) sebagai kreativitas guru dan variabel (y)sebagai motivasi belajar siswa: Jika sig > 0,05 maka Ho diterima Jika sig $<0,05$ maka Ho ditolak

Berdasarkan data yang telah di dapat bahwa signifikan yaitu 0,002 yang berarti lebih kecil dari 0,05 maka Ho ditolak atau ada pengaruh antara kreativitas guru terhadap motivasi belajar siswa.

4. Keterbatasan Peneliti; Peneliti menyadari bahwa penelitian ini tidak luput dari kelemahan-kelamahan. Untuk itu diharapkan kepada siapa saja yang berminat mengadakan penelitian yang relevan mangenai objek ini dapat dilaksanakan dengan lebih sempurna. Selain itu butir-butir angket yang dibuat dalam instrumen-instrumen penelitian mungkin belum sempurna sehingga sulit untuk di pahami oleh siswa. Dengan demikian peneliti berharap aka nada penelitian lebih lanjut.

\section{E. Kesimpulan}

Berdasarkan Pembahasan yang telah peneliti kemukakan pada urian sebelumnya maka dapat Tarik kesimpulan yaitu sebagai berikut;

1. Bahwa kreativitas guru kelas VII di SMP Plus Daarul Jannah Kabupaten Tangerang, 
terbukti dalam kategori sedang dengan persentase $80 \%$ sebanyak 24 anak dari 30 responden.

2. Bahwa motivasi belajar siswa kelas VII di SMP Plus Daarul Jannah Kabupaten Tangerang, terbukti dalam kategori sedang dengan persentase $73,33 \%$ sebanyak 22 anak dari 30 responden.

3. Dari persamaan regresi linier sederhana, maka diperoleh sig < 0,05 yaitu 0,002 < 0,05 maka Ho ditolak, artinya ada pengaruh antara kreativitas guru terhadap motivasi belajar siswa kelas VII di SMP Plus Daarul Jannah Kabupaten Tangerang. Berdasarkan nilai $\mathrm{R}$ square disebut juga koofisien determinasi yang dalam hal ini berarti variabel motivasi belajar dipengaruhi oleh kreativitas guru sebesar $28,3 \%$ sisanya $71,7 \%$ dipengaruhi oleh faktor lain yang dalam penelitian ini belum diteliti.

\section{DAFTAR PUSTAKA}

Abdul basyit dan sahlani, Ilmu Pendidikan Islam (Banten: Pustaka Getok tular, 2017).

Juwariyah, Dasar-Dasar Pendidikan Anak Dalam Al-qur'an (Yogyakarta: Teras, 2010).

Hamza B Uno dan Nurdin Muhammad, Belajar Dalam Pendekatan
PAIKEM (Jakarta: Bumi aksara, 2014).

Mulyasa, Menjadi Guru Professional Menciptakan Pembelajaran Kreatif Dan Menyenangkan (Bandung: remaja rosda karya, 2009).

Muhammad ahsan, sumiyati dan Mustahdi, Pendidikan Agama Islam Dan Budi Pekerti (Jakrta: Kemendikbud, 2017).

Ngalim Purwanto, Psikologi pendidikan (Jakarta: PT. Rosda karya, 2014).

Utami munandar, Pengenbangan Kreativitas Anak Berbakat (Jakarta: Rineka cipta, 2009).

Sardiman AM, Interaksi Dan Motivasi Belajar Mengajar (Depok: PT.Raja Grafindo Persada, 2018).

Sugiono, Metode Penelitian Kuantitatif, Kualitatif Dan $R \& D$ (Bandung: CV. Alfabeta, 2017).

Sri narwati, Creative Learning Kiat Menjadi Guru Kreatif Dan Favorit (Yogyakarta: Kamilia, 2017).

Sahlan asnawi, Teori Motivasi (Jakarta: PT. Studia Pres, 2002).

Sardiman AM, Interaksi Dan Motivasi Belajar Mengajar (Depok: PT. Raja Grafindo Persada, 2018). 
Pengaruh Kreativitas Guru Terhadap Motivasi Belajar Siswa Kelas VII Pada Mata Pelajaran PAI \& BP Di SMP Plus Daarul Jannah Kabupaten Tangerang 